\title{
EVIDÊNCIA GENÉTICA DA INTRODUÇÃO DO CAMARÃO MACROBRACHIUM JELSKII (MIERS, 1877) (CARIDEA: PALAEMONIDAE) NAS BACIAS DO NORDESTE BRASILEIRO E O RELATO DE PSEUDOGENES MITOCONDRIAIS
}

\author{
Moraes, S.A.S.N. ${ }^{1,}$; Rey, G.T.R. ${ }^{2}$; Lima, S.M.Q. ${ }^{1}$ \& Freire, F.A.M. ${ }^{1}$ \\ ${ }^{1}$ Universidade Federal do Rio Grande do Norte (UFRN), Campus Natal, Laboratório de Fauna Aquática. \\ ${ }^{2}$ Universidad de Caldas (UdeC), Sede principal, Facultad Ciencias Exactas y Naturales. \\ *Autor correspondente: savioarcanjo@hotmail.com
}

Macrobrachium jelskii é uma espécie de camarão carídeo de ampla distribuição na América do Sul, contudo, há evidências de introdução acidental desta espécie em corpos d'água, principalmente nos reservatórios do Nordeste do Brasil. Segundo relatos, na década de 40, indivíduos foram introduzidos de forma acidental com outras espécies de peixes e crustáceos. O presente estudo visou sanar os questionamentos sobre a distribuição natural das ocorrências do M. jelskii no Nordeste brasileiro, bem como entender a história biogeográfica da linhagem filogenética. Para o presente estudo foram extraídas, amplificadas e sequenciadas amostras das bacias de Apodi-Mossoró, Jaguaribe, Piranhas-Açú, Paraíba do Norte, São Francisco e Parnaíba, pertencentes a três ecorregiões hidrográficas do Nordeste Médio-Oriental, Maranhão-Piauí e São Francisco. A partir disso foram visualizados os eletroferogramas e inferência filogenética bayesiana (parâmetros: HKY, burn-in 10\% e taxa de mutação de 0,014\%). A inferência filogenética bayesiana revelou monofiletismo entre as linhagens da espécie M. jelskii, com baixa divergência genética entre as bacias do Nordeste brasileiro. As estimativas de estruturação populacional indicam uma baixa diversidade haplotípica (apenas um haplótipo) e diversidade nucleotídica média, sendo um forte indicio a hipótese de introdução não-natural por ações do Departamento de Obras Contra a Seca. Nos eletroferogramas obtidos com os iniciadores universais para o gene COI foram observados alguns picos duplos e muito ruído, provavelmente resultado da co-amplificação de pseudogenes mitocondriais. Os pseudogenes são trechos de material genético que foram duplicados, homólogos aos trechos originais, mas não são funcionais e assim acumulam mutação de forma desordenada, gerando haplótipos que não condizem com uma história evolutiva de uma linhagem. Em muitos artrópodes tem sido evidenciado que estas cópias têm enviesado as estimativas de linhagens filogenéticas dentro de um táxon. Ressalta-se a importância de iniciadores específicos e cuidado em analisar dados de crustáceos, que já apresentam casos de co-amplificação documentado. Além disso, alertamos a presença de pseudogenes presentes em dados publicados que não compartilham nenhum haplótipo e nem mesmo constituem um grupo monofilético com as espécies presentes no gênero Macrobrachium, se mostram na filogenia como grupo externo. Assim, indicando dados prováveis de pseudogenes em plataformas de dados moleculares.

Palavras-chave: camarão-sossego, Decapoda, relações filogenéticas, NuMts. 